\title{
EMPATI
}

VOL. 7 NO. 2 DESEMBER 2018 | 87-101 | DOI: 10.15408/empati.v7i2.11197 p-ISSN: 2301-4261 | e-ISSN: 2621-6418

Website: http://journal.uinjkt.ac.id/index.php/empati

This is an open access article under CC-BY-SA license

(https://creativecommons.org/licenses/by-sa/4.0/)

\section{PERAN PEKERJA SOSIAL DALAM PENDAMPINGAN PSIKOSOSIAL ANAK KORBAN KEKERASAN SEKSUAL DI LEMBAGA KONSULTASI KESEJAHTERAAN KELUARGA (LK3) “MELATI” KABUPATEN KARAWANG}

\author{
Kartika Al Ashzim \\ LK3 UIN Syarif Hidayatullah Jakarta \\ Email: alazhimkartika@gmail.com
}

Received: 3th July 2018; Revised: 14th September 2018; Accepted: 15th December 2018

\begin{abstract}
The occurrence of violence against children in schools, homes, and public places calls for a greater attention for protecting children from physical, psychological and sexual violence. This background is put to understanding the role of social workers in mentoring children victims of sexual violence at LK3 "Melati". This study uses a descriptive qualitative approach. The results of this study prove that LK3 social workers "Melati" provide assistance by client cases consultation and then referring to relevant institutions. The stages of mentoring carried out using case management stages. The method applied by LK3 social worker "Melati" are a casework and case management method. Of the seven roles of social workers according to Zastrow, social workers at LK3 "Melati" use the role of a case manager in psychosocial assistance to children victims of sexual violence.
\end{abstract}

Keywords: The Role of Social Workers, Social Companion, LK3, Child Victims of Violence.

\begin{abstract}
Abstrak. Kekerasan terhadap anak yang terjadi baik di lingkungan sekolah, rumah, maupun di tempat umum menjadi perhatian lebih untuk dapat melindungi anak dari tindak kekerasan, baik kekerasan fisik, psikis maupun seksual. Hal tersebut menjadi latar belakang untuk memahami bagaimana peran pekerja sosial dalam pendampingan anak korban kekerasan seksual di LK3 "Melati". Penelitian ini menggunakan metode kualitatif yang bersifat deskriptif. Hasil penelitian membuktikan bahwa pekerja sosial LK3 "Melati" melakukan pendampingan dengan cara konsultasi kasus klien dan kemudian merujuk ke lembaga-lembaga yang terkait. Sehingga tahapan pendampingan yang dilakukan yaitu memakai tahapan manajemen kasus. Adapun metode yang diterapkan oleh pekerja sosial LK3 "Melati" adalah metode casework dan manajemen kasus. Dari ketujuh peran pekerja sosial menurut Zastrow, pekerja sosial di LK3 "Melati" lebih menggunakan peran sebagai case manager dalam melakukan pendampingan psikososial terhadap anak korban kekerasan seksual.
\end{abstract}

Kata kunci: Peran Pekerja Sosial, Pendamping Sosial, LK3, Anak Korban Kekerasan. 


\section{Pendahuluan}

Anak merupakan cikal bakal lahirnya generasi penerus yang akan menentukan nasib bangsa. Anak merupakan titipan Tuhan yang harus kita lindungi dan kita bimbing. Saat ini banyak anak yang tidak mendapatkan apa yang menjadi haknya. Hal itu mengakibatkan anak mendapatkan perlakuan yang salah dari berbagai pihak. Hal tesebut berdampak pada begitu banyaknya anak yang mengalami kekerasan yang terjadi, baik di sekolah, di rumah, maupun di tempat umum.

Anak akan tumbuh dengan kepercayaan diri yang tinggi karena adanya rasa aman terhadap lingkungannya dan orang lain. Rasa aman juga akan mendorong anak berani melakukan hal positif untuk mengembangkan potensi dirinya. Anak-anak akan memiliki masa depan yang cerah apabila mereka mendapatkan hak-haknya.

Apabila anak sudah tidak merasa aman, memungkinkan anak bisa menjadi korban ataupun pelaku kekerasan. Adapun fokus kekerasan pada anak ada 3 yaitu: di lingkungan keluarga, di lingkungan sekolah dan di lingkungan masyarakat (Ahmadi, 2002).

Berdasarkan klasifikasi yang dilakukan para ahli, tindakan kekerasan atau pelanggaran terhadap hak anak tersebut dapat terwujud setidaknya dalam empat bentuk yaitu: kekerasan fisik, kekerasan psikis, kekerasan seksual, dan kekerasan ekonomi (Suyanto, 2010).

Dalam perundang-undangan, pemerintah sudah menetapkan UndangUndang Nomor 23 Tahun 2002 tentang Perlindungan Anak. Pada pasal 1 tercantum dalam undang-undang ini yang dimaksud dengan anak adalah seseorang yang belum berusia 18 tahun, termasuk anak yang masih dalam kandungan. Sedangkan yang dimaksud dengan perlindungan anak adalah segala kegiatan untuk menjamin dan melindungi anak dan hak-haknya agar dapat hidup, tumbuh, berkembang, dan berpartisipasi, secara optimal sesuai dengan harkat dan martabat kemanusiaan, serta mendapat perlindungan dari kekerasan dan diskriminasi (Huraerah, 2007).

Berdasarkan kasus-kasus yang dilaporkan kepada Komisi Perlindungan Anak Indonesia (KPAI) pada tahun 2015 yang berjumlah 218 kasus, tahun 2016 berjumlah 120, dan tahun 2017 berjumlah 116, ternyata masih banyak masyarakat yang takut untuk melaporkan yang berhubungan dengan kasus kekerasan seksual terhadap anak. 
Tabel 1

Data Kasus Kekerasan Seksual Pada Anak dari

Tahun 2015 Sampai Tahun 2017

\begin{tabular}{cc}
\hline TAHUN & JUMLAH KASUS \\
\hline 2015 & 35 kasus \\
\hline 2016 & 45 kasus \\
\hline 2017 & 100 kasus \\
\hline
\end{tabular}

Sumber: Hasil Laporan Kegiatan pendampingan kasus oleh LK3 "Melati" Dinas Sosial kabupaten Karawang 2015-2017.

Adapun pelaku yang rentan melakukan tindakan kekerasan seksual terhadap anak adalah orang terdekat anak seperti ayah tiri dan kandung, keluarga terdekat, maupun teman terdekat (http:// www.kpai.go.id, 2018). Oleh sebab itu, anak-anak begitu renta menjadi target kekerasan. Keberadaan anakanak di lingkuangan keluargapun tidak menutup kemungkinan menjadi sasaran kekerasan seksual dari orang terdekat mereka. Sebagaimana data dari National Sexual Violence Resource Center memperlihatkan, sekitar 90 persen pelaku pelecehan seksual masih mempunyai hubungan keluarga dengan korban atau berasal dari lingkungan terdekat seperti tetangga, teman keluarga, guru, pelatih olahraga (http://www.bp3akb.jabarprov.go.id/, 2017).

Sejak tahun 2009, Kementerian Sosial RI melalui Direktorat Jenderal Pemberdayaan Sosial dan Penanggulangan Kemiskinan membentuk Lembaga Konsultasi Kesejahteraan Keluarga (LK3).

Hingga tahun 2013, LK3 di Indonesia berjumlah 631 LK3, yang terdiri dari 1 LK3 Kementerian Sosial RI, 1 LK3 STKS Bandung, 485 LK3 kabupaten kota di 33 provinsi dan 124 LK3 berbasis masyarakat yaitu yayasan atau Lembaga Kesejahteraan Sosial (LKS) yang melaksanakan layanan LK3 serta 20 LK3 perguruan tinggi yang memiliki jurusan Ilmu Kesejahteraan Sosial atau pekerjaan sosial. Kondisi keberadaan LK3 tersebut sangat bervariasi baik dari segi kualitas dan kuantitas sumber daya manusia, sarana dan prasarana yang memiliki maupun kualitas layanan yang diberikan kepada masyarakat. Hal ini sebagai upaya dalam memperluas jangkauan kerja penanganan masalah psikososial (Kementerian Sosial RI, Direktorat Jenderal Pemberdayaan Sosial dan Penanggulangan Kemiskinan, 2014)

Peneliti mengambil objek penelitian di Lembaga Konsultasi 
Kesejahteraan Keluarga (LK3) "Melati” yang berada di Dinas Sosial Kabupaten Karawang. LK3 "Melati” termasuk dalam LK3 kabupaten yang penetapannya secara struktural ditetapkan oleh bupati masing-masing. Peneliti memilih LK3 "Melati" Kabupaten Karawang dikarenakan LK3 tersebut dinobatkan menjadi LK3 terbaik tingkat nasional dan menjadi LK3 percontohan bagi daerah lain di luar pulau Jawa untuk study banding.

Peneliti memperoleh data kasus-kasus yang didampingi oleh LK3 "Melati" sejak bulan Januari sampai November 2017. Ada beberapa kasus yang ditangani oleh LK3 “Melati” yaitu terdapat 6 kasus adopsi anak, 5 kasus Kekerasan Dalam Rumah Tangga (KDRT), 100 kasus pelecehan seksual, 16 kasus tawuran remaja, dan 33 kasus Anak berhadapan dengan Hukum (ABH). Sehingga total semua kasus berjumlah 160 kasus dan meningkat dibanding tahun 2016 yang hanya berjumlah 154 kasus untuk semua kasus. Kasus pelecehan seksual yang paling terbanyak di tahun 2017.

Peneliti memilih kategori usia anak korban kekerasan seksual yang didampingi oleh LK3 “Melati” yaitu usia 13 tahun sampai 17 tahun. Usia tersebut termasuk dalam kategori usia remaja awal, menurut (Hurlock, 1978) dimana saat usia tersebut terjadi ketidakseimbangan emosional, mencari identitas diri, dan hubungan sosial yang berubah. Sesuai dengan Undang-Undang Perlindungan Anak Nomor 23 Tahun 2002, bahwa salah satu upaya perlindungan khusus bagi anak korban kejahatan seksual berupa pendampingan psikososial. Maka dari itu, LK3 "Melati" memberikan pelayanan berupa pendampingan. Pendampingan merupakan tindak lanjut dari pelayanan yang diberikan oleh LK3 "Melati" Kabupaten Karawang yang ditujukan bagi anak korban kekerasan seksual. Dalam hal ini pekerja sosial LK3 "Melati" menjadi pendamping bagi korban atau pelaku anak yang mengalami kekerasan seksual. Dalam pendampingan disini, pekerja sosial LK3 “Melati” Kabupaten Karawang memberikan pendampingan psikososial bagi anak korban yang terindikasi masalah psikososial ataupun tidak terindikasi.

Pekerja sosial LK3 “Melati” menggunakan proses pertolongan pekerjaan sosial dalam menangani kasus kekerasan seksual terhadap anak. Selama proses penanganan kasus berjalan, pekerja sosial tidak hanya menitikberatkan pada klien tetapi juga harus melihat kodisi lingkungan sekitarnya. Sehingga klien mampu meningkatkan potensi dan dukungan sosialnya. Selain itu, pekerja sosial mengaplikasikan beberapa peran dalam memberikan pendampingan pada anak-anak korban kekerasan seksual. 


\section{Metode}

Pada penelitian ini, penulis menggunakan metode penelitian kualitatif. Beberapa ahli memberikan definisi penelitan kualitatif tidak jauh berbeda. (Denzin dan Lincoln, (2009), pendekatan kualitatif adalah suatu proses penelitian dan pemahaman yang berdasarkan pada metodologiyang menyelidiki suatu fenomena sosial dan masalah manusia. Pada pendekatan ini, peneliti menekankan sifat realitas yang terbangun secara sosial, hubungan erat antara peneliti dan subjek yang diteliti. Penelitian kualitatif adalah suatu penelitian ilmiah yang bertujuan untuk memahami suatu fenomena dalam konteks sosial secara alamiah dengan mengedepankan proses interaksi komunikasi yang mendalam antara peneliti dengan fenomena yang diteliti (Herdiansyah, 2010).

Berdasarkan pertimbangan untuk menyajikan data yang akurat dan untuk mendapatkan gambaran yang jelas dari kondisi di lapangan. Peneliti menggunakan penedekatan kualitatif dalam meneliti kasus pendampingan psikososial anak korban kekerasan seksual di Lembaga Konsultasi Kesejahteraan Keluarga (LK3) “Melati” Dinas Sosial kabupaten Karawang.

Jenis penelitiannya yakni Penelitian deskriptif, hal tersebut dimaksdukan untuk memberikan penyajian yang akurat dalam mendeskripsikan suatu kasus atau pun peristiwa. Penggunaan jenis penelitian ini bertujuan untuk menggambarkan sifat suautu keadaan dan tanpa memberikan memberikan perlakuan khusus pada peristiwa tersebut.

\section{Hasil dan Diskusi}

\section{Dasar Hukum Pendampingan Psikososial}

Dalam kasus kekerasan seksual terhadap anak yang semakin banyak terjadi, LK3 "Melati" Kabupaten Karawang bersama Polres Karawang mengoptimalkan pemberian hak anak untuk mendapatkan perlindungan. Pemerintah dan lembaga negara lainnya berkewajiban dan bertanggungjawab untuk memberikan perlindungan khusus kepada anak korban kejahatan seksual. Sesuai dengan Undang-Undang Republik Indonesia Nomor 35 tahun 2014 tentang Perubahan Atas Undang-Undang Nomor 23 tahun 2002 tentang Perlindungan Anak. 


\section{Pendampingan Psikososial Terhadap Anak Korban}

\section{Kekerasan Seksual Yang Dilakukan oleh Pekerja Sosial}

Pendampingan merupakan tindak lanjut dari pelayanan yang diberikan oleh LK3 "Melati" Kabupaten Karawang yang ditujukan bagi anak korban kekerasan seksual. Kasus tersebut merupakan masalah serius yang mengancam jiwa anak-anak. Kekerasan seksual adalah bentuk kekerasan berbasis gender yang paling sering terjadi dan paling berbahaya yang terjadi pada masa sekarang. Untuk menyelamatkan jiwa dan meningkatkan perlindungan, ada tindakantindakan yang harus segera dilaksanakan secara terkoordinasi untuk mencegah dan menangani kasus kekerasan seksual terhadap anak.

Anak korban kekerasan seksual atau anak yang berhadapan dengan hukum harus mendapatkan perlindungan. Sesuai dengan Undang-Undangnomor 11 tahun 2012 pasal 3 tentang Sistem Peradilan Pidana Anak, dijelaskan bahwa setiap anak dalam proses peradilan pidana berhak memperoleh pendampingan. Sesuai dengan Undang- Undang nomor 23 tahun 2002 tentang Perlindungan Anak, pada pasal 1 ayat (14) yang dimaksud dengan pendamping adalah pekerja sosial yang mempunyai kompetensi profesional dalam bidangnya.

Fungsi pendampingan yaitu memberikan pelayanan lanjutan kepada klien. Hal ini terkait pada fungsi manajemen kasus dalam memberikan pelayanan pada klien secara individu. Manajemen kasus dirancang untuk menjawab "pelayanan yang tidak terorganisir dalam penanganan kondisi klien bermasalah jangka panjang, dan pelayanan masyarakat yang terus berubah dan terbatas." (Roberts dan Albert, 2008).

Maka dari itu tahapan pendampingan yang dilakukan oleh pekerja sosial LK3 "Melati" yaitu memakai tahapan manajemen kasus. Pendampingan dilakukan secara sistematis namun juga disesuaikan dengan kebutuhan dan permasalahan klien.

\section{Tahapan Manajemen Kasus Pada Klien Anak Korban Kekerasan Seksual}

Lembaga Konsultasi Kesejahteraan Keluarga (LK3) "Melati” Kabupaten Karawang merupakan media konsultasi bagi individu dan keluarga yang mengalami masalah psikososial dalam keluarganya, serta terganggu peran dan fungsi sosialnya. Dari hasil observasi selama tiga bulan, peneliti mengikuti kegiatan pendampingan di LK3 “Melati” Kabupaten Karawang. Kegiatan tersebut 
dilakukan dari bulan Oktober hingga Desember 2017 agar dapat melihat langsung bagaimana tahapan pendampingan yang dilakukan di LK3 "Melati" terhadap klien.

\section{Akses ke Lembaga}

Dalam melakukan sistem penerimaan klien di LK3 "Melati" hanya ada dua cara, yaitu ada yang dengan rujukan dan ada yang datang langsung. Proses penerimaan klien juga berjalan dengan normal, tanpa ada pungutan biaya bagi klien. Surat masuk dari Polres Karawang sebagai surat rujukan kepada LK3 "Melati" untukdilakukan pendampingan terkait proses penyidikan sehubungan dengan jenis kasus yang tertera pada surat masuk tersebut. LK3 "Melati" Kabupaten Karawang menggunakan metode intervensi pada individu (Casework) yaitu terkait dengan upaya memperbaiki atau meningkatkan keberfungsian sosial individu, serta menggunakan metode manajemen kasus. Pekerja sosial menggunakan pendekatan pekerjaan sosial dalam penanganan masalah dengan saling berhubungan.

\section{Intake}

Intake yang dimaksud adalah pekerja sosial LK3 “Melati” mengidentifikasi masalah dan situasi klien anak korban kekerasan seksual. Pekerja sosial berupaya menentukan apakah ada jenis layanan yang sesuai dengan kebutuhan klien. Terdapat proses pengumpulan informasi, pengisian formulir dan memberi petunjuk kepada klien. Terlebih dahulu pekerja sosial menyiapkan formulir penerimaan klien serta pernyataan kesediaan untuk bekerja sama dengan petugas LK3 "Melati" Kabupaten Karawang melakukan tindak lanjut yang dibutuhkan bagi permasalahan klien.

\section{Asesmen}

Asesmen yang dilakukan oleh pekerja sosial LK3 "Melati" bertujuan untuk memahami sebab dan dinamika masalah. Pada tahap ini tingkat keberfugsian sosial, psikologis, dan fisik klien diklarifikasi dalam arti lain asesmen merupakan penggalian masalah yang sedang dialami klien. Pekerja sosial LK3 "Melati" Kabupaten Karawang melakukan asesmen terhadap klien anak korban kekerasan seksual dengan menggunakan beberapa tools atau alat bantu seperti BPSS dan ecomap. 
Peneliti telah meminta izin kepada pihak LK3 "Melati" Kabupaten Karawang untuk mengambil data beberapa klien anak korban kekerasan seksual untuk dijadikan informan penelitian skripsi. Peneliti membatasi usia klien anak korban kekerasan seksual antara usia 13 hingga 18 tahun.

Adapun klien yang menjadi informan yaitu klien "M" yang berusia 17 tahun, klien mengalami sodomi oleh pelaku " $\mathrm{A}$ "yang merupakan orang yang baru dikenalnya. Klien mengalami kejadian itu sudah lebih lima kali oleh pelaku yang sama, Klien "S" yang berusia 13 tahun, mengalami pelecehan seksual oleh ayah kandung korban. Klien mengalami kejadian itu hanya sekali, dan Klien "J" yang berusia 16 tahun, mengalami pelecehan seksual oleh pelaku "A"yang merupakan tetangga dari korban. Klien mengalami kejadian itu hanya sekali.

\section{Penentuan Tujuan}

Penentuan tujuan didasarkan pada asesmen yang telah dilakukan oleh pekerja sosial LK3 "Melati". Setelah mengidentifikasi permasalahan dan kekuatan klien secara mendalam, tahap berikutnya yang dilakukan oleh pekerja sosial LK3 "Melati" Kabupaten Karawang adalah bekerja bersama dengan klien anak korban kekerasan seksual. Pekerja sosial LK3 "Melati" memberikan kepercayaan kepada klien untuk menemukan tujuan hidupnya.

Pekerja sosial memasukkan tujuan pribadi klien untuk mengetahui harapan klien dalam pendampingan. Harapan akan adanya kebutuhan yang ingin dipenuhi. Pada klien "J" yang memiliki harapan terhadap pendampingan yaitu menurunkan kecemasan pada dirinya, memperoleh jawaban dari persoalan yang dihadapi, dan mencari upaya agar dirinya lebih baik dan berkembang.

Klien "J" berharap pekerja sosial LK3 "Melati" dapat membantu dirinya dalam menghilangkan trauma yang dialaminya serta membantu dirinya agar bisa sekolah lagi dengan cara mencarikan sekolah baru untuknya.

Selainitu, Klien "S" juga memiliki harapan terhadap pendampingan untuk menyelesaikan permasalahannya. Klien "S" mengalami pelecehan seksual yang dilakukan oleh ayah kandungnya. Klien "S" berusaha untuk melaporkan kejadian tersebut ke Polres Karawang bersama dengan ibu kandungnya. Setelah itu datang langsung ke LK3 “Melati” untuk meminta pertolongan kepada pekerja sosial supaya dapat membantu menyelesaikan masalah yang dialaminya. Harapannya agar klien "S" dapat menjalani kehidupannya dengan baik seperti anak-anak lainnya. 


\section{Merencanakan Intervensi}

Perencanaan intervensi mencakup perencanaan penanganan dalam arti pemberian konseling langsung dan terapi. Perencanaan berkaitan erat dengan identifikasi sumber daya dan hubungan- hubungan yang saling terkait.

Dalam menyusun recana, pekerja sosial mengidentifikasi kekuatan dan potensi klien, hal itu dapat digunakan klien sebagai alternatif-alternatif pemecahan masalah yang diberikan pekerja sosial LK3 "Melati" Kabupaten Karawang. Menyadari kekuatan dan potensi yang dimiliki klien "J", “M", dan "S" itu akan membantu mereka dalam membangun apa yang mereka butuhkan untuk segera dicarikan solusi alternatif yang baik bagi mereka. Adapun potensi yang dimiliki masing- masing klien, yaitu:

Pertama, Klien "J" memiliki usia muda, sehingga masih bisa diarahkan dan potensial untuk dikembangkan lagi ke hal-hal yang positif; Memiliki keluarga (orangtua lengkap) yang dapat mendidik, mengontrol, dan memenuhi kebutuhan sesuai perkembangan klien; Masih punya keinginan untuk melanjutkan sekolah dan meraih cita- citanya; Hidup di lingkungan masyarakat yang mempunyai norma dan etika; Memiliki mental dan fisik yang sehat. Kedua, Klien "M" memiliki usia produktif; Memiliki ibu dan kakak; Memiliki fisik yang sehat; Mempunyai cita-cita; Mempunyai relasi yang baik dengan lingkungannya; Mempunyai niat untuk memperbaiki sikap dan perilakunya; Tinggal di lingkungan masyarakat yang mempunyai norma-norma. Ketiga, Klien "S" memiliki usia produktif; Memiliki ibu, kakak, dan adik; Memiliki harapan tinggi untuk memiliki keluarga yang utuh; Memiliki fisik yang sehat; Memiliki keberanian.

Peneliti mendapatkan sumber tersebut dari hasil asesmen klien oleh LK3 "Melati" Kabupaten Karawang. Dari tabel di atas dapat dilihat bahwa potensi yang dimiliki masing-masing klien sebagai kekuatan yang dapat menolong klien dalam proses pendampingan agar berjalan sesuai dengan apa yang diinginkan.

Dari hasil asesmen yang dilakukan pada klien "J", “M", dan "S", bahwa masing-masing klien masih berusia produktif dan memiliki fisik yang sehat, serta masih memiliki cita-cita yang ingin dicapai. Pekerja sosial LK3 "Melati" bisa menyampaikan kepada klien bahwa pekerja sosial percaya terhadap potensi klien untuk memperbaiki dirinya.

Anak korban kekerasan seksual mengalami dampak psikologis dan sosial yang berkepanjangan hingga dewasa. Secara psikis bisa menimbulkan ketagihan, trauma, bahkan pelampiasan dendam. Bila tidak ditangani serius, 
kekerasan seksual terhadap anak dapat menimbulkan dampak sosial yang luas di masyarakat. Oleh sebab itu, pekerja sosial LK3 “Melati” Kabupaten Karawang memprioritaskan apa yang dibutuhkan klien "J", "M", dan "S". Berikut solusi alternatif dari masing-masing klien.

Klien “J" 1) Kepada klien, untuk tempat tinggal klien agar bisa dipindahkan ke tempat neneknya untuk menghindari hal-hal yang tidak diinginkan. Klien juga dipindahkan sekolahnya ke sekolah barunya dideket rumah nenek klien; 2) Kepada kedua orangtua klien agar lebih perhatian lagi dan mengasuh anak dengan kasih sayang. Menyediakan waktu untuk klien agar klien dapat menceritakan apa yang ada dalam pikirannya; 3) Kepada pihak sekolah agar dapat membantu kelancaran keberlanjutan sekolah untuk klien, sehingga keinginannya untuk melanjutkan pendidikan dapat terwujud; 4) Kepada pihak masayarakat agar lebih peduli dalam kontrol sosial terhadap lingkungannya. Sehingga tercipta kenyamanan dan keamanan lingkungan.

Klien "M" 1) Kepada klien agar bisa dirujuk ke psikiater untuk penanganan lebih lanjut berkaitan dengan orientasi seksualnya. Serta klien lebih berhati-hati lagi dalam bergaul dan memilih teman; 2) Kepada keluarga klien khususnya ibu dan kakaknya agar melakukan pengawasan lebih baik terhadap perkembangan sikap, perilaku, dan kegiatan klien, baik di lingkungan tempat tinggal maupunsekolahnya;

3) Kepada pihak sekolah agar lebih meningkatkan lagi kontrol sosialnya kepada murid-muridnya. Dan di sekolahnya disediakan tempat untuk murid dapat mencurahkan permasalahannya.

Klien "S" 1) Kepada klien agar tetap menganut agama Islam, tanpa ada paksaan dari pihak manapun; 2) Kepada kedua orangtua klien agar memberikan perhatian dan kasih sayangnya kepada klien. Membantu spiritual klien untuk pindah ke agama Islam, serta lebih dekat dengan klien agar klien bisa menceritakan permasalahannya.

3) Kepada pihak sekolah agar dapat membantu klien dalam hal perkembangan spiritual klien sehingga dapat mencegah dampak buruk dari peristiwa yang dialami klien.

Peneliti mendapatkan sumber tersebut dari hasil asesmen klien oleh LK3 "Melati" Kabupaten Karawang. Dari tabel diatas dapat dilihat bahwa pekerja sosial LK3 "Melati" Kabupaten Karawang bersama dengan klien membuat solusi alternatif tersebut sesuai dengan kebutuhan mendesak bagi klien untuk 
dilakukan penanganan tindak lanjut oleh tim LK3 “Melati” Kabupaten Karawang.

\section{Identifikasi Sumber Daya}

Setelah mengetahui apa yang dibutuhkan oleh klien, ternyata untuk klien "M" dan "S" membutuhkan rujukan kepada sumber pelayanan yang sesuai dengan kebutuhan. Pekerja sosial LK3 "Melati" Kabupaten Karawang menghubungi sumber pelayanan yang menerima rujukan. Pada klien "M" sesuai kebutuhan dari permasalahannya, klien dirujuk ke psikiater untuk penanganan lebih lanjut berkaitan dengan orientasi seksualnya. Pada klien "S" sesuai kebutuhan dari permasalahannya, klien dirujuk ke Lembaga Pemberdayaan Kujang (Baitul Maal) dengan mengikuti program-program pemberdayaan untuk klien dan ibunya. Agar klien dan ibunya balik lagi ke agama Islam. Setelah pekerja sosial memberikan sumber pelayanan yang relevan kepada klien "S", “M", dan "J", tahap selanjutnya adalah mengaitkan klien dengan dukungan formal (lembaga) dan dukungan informal (keluarga, teman-teman, tetangga, dan masyarakat).

\section{Pemantauan (Monitoring)}

Hubungan sistematis dengan lembaga pemberi layanan dan dukungan informal adalah inti pemantauan. Tujuannya adalah untuk menilai kesesuaian bantuan untuk membantu klien berfungsi dalam masyarakat. Pekerja sosial LK3 "Melati" melakukan pemantauan terhadap kliennya melalui telepon dengan lembaga pelayanan yang menerima rujukan, mengunjungi atau menelepon klien, atau meminta pedukung informal dan klien menelepon pekerja sosial yang ada di LK3 "Melati."

Akhir pendampingan dari Klien J", "M", dan klien "S" adalah dengan merujuk klien kepada masing-masing sumber pelayanan yang sesuai dengan kebutuhan klien.

\section{Pendampingan Psikososial yang Dilakukan oleh Psikolog di LK3 “Melati” Kabupaten Karawang}

Selain pendampingan yang dilakukan oleh pekerja sosial yang sudah dijelaskan di atas, LK3 “Melati” Kabupaten Karawang juga bekerjasama dengan psikolog untuk menangani dan mengetahui emosional anak korban kekerasan seksual. Sebagai korban pelecehan seksual, anak biasanya akan mengalami perasaan trauma. Walaupun kejadian trauma tersebut telah terjadi selama bertahun-tahun bahkan belasan tahun, tetapi bekas trauma tersebut susah 
hilang. Seperti anak korban yang didampingi oleh psikolog di LK3 "Melati" yang sebagian besar mengalami kondisi emosional yang bermacam-macam yang diakibatkan oleh yang dialami korban. Adanya kelekatan emosional antara anggota keluarga dengan saling jujur dan terbuka membuat anak mudah menjalin komunikasi yang efektif dan harmonis. Sehingga anak mampu mengontrol emosionalnya dengan baik.

Psikolog LK3 "Melati” meminta klien untuk menggambar dasar (rumah, pohon, manusia) pada selembar kertas. Jika klien sudah selesai menggambar dasar tersebut, maka gambar tersebut dianalisis oleh psikolog agar dapat dipahami keadaan dan kondisi psikologis klien. Dan hasil dari kesimpulan gambar itu diberikan kepada pekerja sosial. Anak korban yang mengalami pelecehan seksual yang ditangani oleh psikolog LK3 "Melati" Kabupaten Karawang ini sangat membutuhkan dukungan sosial dan emosional dari orangtua untuk mengembalikan semangat hidupnya yang hilang. Jadi psikolog di LK3 "Melati" tidak hanya memberikan pendampingan pada anak korbannya saja, tetapi kepada orangtua korban juga. Hal itu guna membangun kedekatan dan keterbukaan antara anak dengan orangtua yang selama ini kurang baik.

\section{Peran Pekerja Sosial dalam Mendampingi Anak Korban Kekerasan Seksual}

Menurut (Raharjo, 2015) terdapat tujuh peran yang biasa dilakukan oleh pekerja sosial. Peran-peran tersebut dijalankan dalam proses pemberian bantuan terhadap klien. Peranan yang satu dengan peranan yang lainnya saling menunjang dan saling melengkapi. Seperti pada kegiatan pendampingan bagi anak korban kekerasan seksual yang dilakukan oleh pekerja sosial LK3 "Melati" Kabupaten Karawang, pekerja sosial telah mampu melaksanakan tugas dan perannya dengan baik. Meskipun memiliki hambatan dalam melaksanakan peranannya, sehingga peranannya kurang maksimal.

Pekerja sosial LK3 "Melati" Kabupaten Karawang memainkan beberapa peran pekerja sosial dengan baik pada saat memberikan pendampingan terhadap anak korban kekerasan seksual yaitu sebagai konselor, motivator, advokat, broker, enebler, dan mediator. Namun, dalam tahapan manajemen kasus ini, pekerja sosial LK3 "Melati" lebih melaksanakan peranannya sebagai case manager dalam melakukan pendampingan psikososial yang diberikan kepada klien anak korban kekerasan seksual. 
Selama menjadi case manager, pekerja sosial LK3 "Melati" memiliki tugasnya yaitu mengumpulkan informasi dan menilai situasi klien agar dapat mengidentifikasi kebutuhan dan masalah. Serta menempatkan dan menyediakan pelayanan, menyusun dan menyampaikan pelayanan yang dibutuhkan bagi klien serta mengkoordianasikan bantuan dari pelayanan-pelayanan tersebut.

\section{Diskusi Analisis: Peran Pekerja Sosial dalam Pendampingan Masalah Psikososial Anak Korban Kekerasan Seksual dalam Perspektif Islam}

Pada saat pekerja sosial LK3 "Melati" melakukan pendampingan pada anak korban kekerasan seksual, pekerja sosial mengaplikasikan beberapa peran pekerja sosial yang berkaitan dengan tugas dan fungsi pekerjaan sosial. Dalam menjalankan perannya, pekerja sosial LK3 "Melati" mengedepankan nilainilai kemanusiaan yang bertujuan untuk mengembalikan keberfungsian sosial seseorang. Artinya, pekerja sosial memiliki tugas untuk mengembalikan fungsi sosial setiap klien agar menjadi manusia yang lebih baik. Tugas tersebut sangat mulia, sebagaimana tugas yang diberikan Allah SWT kepada manusia.

Dalam menganalisa temuan di LK3 "Melati" Kabupaten Karawang, peneliti sangat tertarik untuk mengintegrasikan antara peran pekerja sosial dengan Islam. Oleh karena itu, pekerja sosial dalam perannya harus memandang dan menimbang dengan Al-Qur'an dan Hadits sebagai pedoman dasar dari kegiatan pendampingan anak korban kekerasan seksual dengan mengaitkan teori pekerjaan sosial.

Berdasarkan ayat Al-Qur'an dan Hadits, pekerja sosial LK3 "Melati" Kabupaten Karawang memiliki peran yang sangat penting dalam membantu atau memberikan pertolongan kepada anak korban kekerasan seksual. Hal tersebut peneliti simpulkan berdasarkan teori pekerjaan sosial bahwa, pekerjaan sosial adalah suatu profesi pertolongan yang didasarkan tiga kerangka dasar konsep keilmuan yaitu nilai, pengetahuan dan keterampilan.

Pemberian pertolongan seorang hamba terhadap saudaranya itu dapat menyebabkan pertolongan Allah kepada hamba tersebut. Dalam hadits tersebut terdapat motivasi untuk menolong sesama saudara dari kaum muslimin yang butuh pertolongan dari segala perkara yang mereka hadapi. Allah ta'ala juga telah menyebutkan perintah tolong- menolong dalam firmannya dalam surah al-Maidah [5]: 2. 


\section{Kesimpulan}

Berdasarkan penelitian yang telah dilakukan terhitung sejak Oktober 2017 hingga Desember 2017, peneliti menemukan beberapa ketentuan yang ada di Lembaga Konsultasi Kesejahteraan Keluarga (LK3) "Melati” Kabupaten Karawang khususnya pada peran pekerja sosial dan tahapan pendampingan bagi anak korban kekerasan seksual.

Di ketahui bahwa Lembaga Konsultasi Kesejahteraan Keluarga (LK3) "Melati" Kabupaten Karawang menjalankan fungsinya sebagai unit layanan sosial terpadu atau "center link" yang memiliki program pelayanan berupa penanganan masalah psikososial keluarga. Dalam hal ini lembaga menangani individu, kelompok maupun masyarakat umum yang mengalami masalah psikososial, dan tentu tidak terlepas dari keluarga. Salah satu pelayanan yang diberikan oleh LK3 "Melati" yaitu pendampingan. Pekerja sosial LK3 "Melati" melakukan pendampingan psikososial terhadap klien anak korban kekerasan seksual dengan cara konsultasi kasus klien dan kemudian merujuk ke lembagalembaga yang terkait.

Untuk memberikan pendampingan psikososial bagi anak korban kekerasan seksual, LK3 "Melati” menggunakan pendekatan pekerjaan sosial secara mikro yang merujuk pada keahlian pekerja sosial dalam menangani permasalahan yang dihadapi oleh individu. Adapun metode yang diterapkan oleh pekerja sosial LK3 "Melati" adalah metode casework dan metode manajemen kasus. Tahapan pendampingan yang dipakai adalah tahapan manajemen kasus.

Meskipun pendampingan yang diberikan oleh LK3 "Melati" belum maksimal, secara umum peneliti dapat menyimpulkan bahwa pendampingan bagi anak korban kekerasan seksual di Lembaga Konsultasi Kesejahteraan Keluarga (LK3) "Melati" Kabupaten Karawang sangat penting. Belum maksimalnya pendampingan psikososial yang diberikan dikarenakan fasilitas yang tidak memadai antara yang harus ditangani dengan fasilitas yang ada, seperti hanya ada dua ruangan konseling yang tersedia, sementara harus ada ruangan isolasi dan ruangan terapi yang orang lain tidak boleh mengetahui dan mendengar. Dan kurangnya tenaga pekerja sosial di LK3 “Melati” padahal setiap hari kasus kekerasan seksual selalu ada.

Lembaga Konsultasi Kesejahteraan Keluarga (LK3) "Melati" Kabupaten Karawang menggunakan beberapa peran pekerja sosial yaitu konselor, motivator, 